\title{
Integrasi Pendidikan Berbasis Lingkungan dengan Nilai-nilai Islam: Upaya Meningkatkan Etika dan Literasi lingkungan
}

\author{
Muh. Idris ${ }^{1}$, Sabil Mokodenseho ${ }^{2}$, Evra Willya ${ }^{3}$, Yusno Abdullah Otta ${ }^{4}$ \\ ${ }^{1}$ Institut Agama Islam Negeri Manado, Indonesia \\ Email: idristunru02@gmail.com \\ ${ }^{2}$ Universitas Islam Negeri Syarif Hidayatullah Jakarta, Indonesia \\ Email: sabil.mokodenseho@gmail.com \\ ${ }^{3}$ Institut Agama Islam Negeri Manado, Indonesia \\ Email: evrawillya@iain-manado.ac.id \\ ${ }^{4}$ Institut Agama Islam Negeri Manado, Indonesia \\ Email: yusno.otta@iain-manado.ac.id
}

\begin{abstract}
Educating students through a learning process is not only aimed to enable them to obtain knowledge and skill in various things but also, ethical formation is an essential part of the education objective itself. Knowledge, expertise, and ethics can be achieved through problem-based learning with a socio-scientific context integrated with Islamic values. Problem-solving with socio-context issues has strengthened students' engagement in environmental issues, and their involvement is finally able to improve their understanding of environmental problems. Islamic values which integrated with knowledge are believed to influence students' mindset and perception. Ethics and sensitivity to the environment begin with the way they view and act on the environment. An effective environmental educational concept can strengthen environmental literacy and readiness to behave well concerning the environment. Problem-based learning is learning using the problem as a starting point for learning. This learning has directed students to seek and determine relevant sources with knowledge. Therefore, this learning challenges students to build knowledge independently.
\end{abstract}

Keywords: Integration; Education; Islamic Values; Environmental Ethics; Environmental Literacy

\section{Pendahuluan}

Perkembangan sains dan teknologi tidak dapat dipungkiri menjadi bagian penting bagi kehidupan manusia [1-2]. Sains dan teknologi kerap digunakan sebagai acuan dalam menginterpretasikan dan memahami lingkungan sekitar beserta isinya [3-4]. Namun, karena adanya pembangunan di berbagai sektor kehidupan telah membawa dampak pada penurunan kualitas lingkungan [5]. Kita bisa lihat di setiap sektor kehidupan, sains dan teknologi digunakan sebagai alat untuk mengeksploitasi, mengolah dan memanfaatkannya untuk pemenuhan kebutuhan manusia [6-7]. Oleh karena itu, agar generasi kita bisa menghadapi berbagai tantangan lingkungan, sudah seharusnya ada upaya-upaya yang dilakukan seperti mendidik dan menginformasikan kepada masyarakat umum tentang masalah-masalah lingkungan dan bahaya yang ditimbulkannya akibat pengelolaannya yang tidak tepat. Salah satu solusi alternatif adalah komitmen kita bersama dan juga pemerintah [8] untuk melindungi bumi dari polusi melalui penerapan pendidikan lingkungan [9] sebagai kunci untuk mempersiapkan masyarakat dengan pengetahuan, keterampilan, nilai dan sikap kepedulian terhadap lingkungan, serta dapat berpartisipasi aktif dalam memecahkan masalah-masalah yang berkaitan dengan lingkungan [10-11].

Banyak studi menunjukkan bahwa hasil dari pelaksanaan pendidikan lingkungan di sekolah cukup beragam, utamanya kesiapan untuk bertindak. Ini dirasakan di berbagai lembaga pendidikan, baik pendidikan rendah maupun pendidikan tinggi di dunia. Temuan Bedural mengatakan perlu meninjau kembali pendidikan lingkungan di Filipina, yakni disarankan untuk beralih dari pendidikan tentang lingkungan ke pendidikan untuk lingkungan [12]. Selanjutnya, mata pelajaran seperti studi sosial harus memperkuat pendidikan kewarganegaraan dengan memasukkan pelajaran tentang lingkungan, terutama pada partisipasi dan tindakan. Tidak sedikit juga hasil studi yang menawarkan langkah-langkah yang harus ditempu agar tujuan pendidikan lingkungan bisa tercapai. Suryani dkk., menguji beberapa aspek pembelajaran dalam pendidikan lingkungan melalui pengembangan sekolah hijau di MI Walisongo menemukan bahwa pendidikan lingkungan membutuhkan berbagai 
pengalaman belajar yang berkaitan dengan emosi, praktik langsung dan pengembangan kognitif. Pengalaman tersebut dapat diwujudkan dalam beberapa proses pembelajaran, yakni pembelajaran partisipatif, pemodelan, pembangunan karakter, dan pembangunan situs hijau, serta pembelajaran melalui permainan dan kerja tim [13]. Senada dengan Suryani, Yasin menganalisis implementasi program adiwiyata dalam pengembangan kesadaran lingkungan di sekolah adiwiyata mandiri SMAN 1 Kajen, Pekalongan. Hasil penelitian menunjukkan implementasi program adiwiyata dapat dilakukan melalui empat aspek penting, yakni kebijakan sekolah ramah lingkungan; kurikulum sekolah berbasis lingkungan; manajemen infrastruktur yang mendukung ramah lingkungan; partisipatif berbasis aktivitas dan keseluruhan berkontribusi positif dalam menciptakan situasi dan kondisi yang mendukung pengembangan kesadaran lingkungan [14]. Rekomendasi dari dua penelitian sebelumnya mirip dengan hasil penelitian Saprodi, Kastolani dan Ningrum terkait integrasi pendidikan lingkungan di pesantren Daarut Tauhid Bandung. Penelitian mereka menunjukkan bahwa mengintegrasikan pendidikan lingkungan di sekolah dapat dilakukan melalui tiga cara. Pertama, integrasi pendidikan lingkungan melalui kurikulum nasional, yaitu peningkatan sumber daya manusia, pelatihan, penjangkauan, manual, dan program. Kedua, integrasi melalui kurikulum sekolah asrama, yaitu program Bersih, Rapi, Tertib dan Terorganisir (BRTT) dan program Bersih, Hijau dan Berbunga (Berhiber). Ketiga, integrasi pendidikan lingkungan melalui pembelajaran. Lebih lanjut mereka merekomendasikan pelaksanaan program pendidikan lingkungan dan sekolah ramah lingkungan di sekolah dapat menyentuh dengan menyeimbangkan aspek kognitif, afektif dan psikomotor siswa [15].

Terlepas dari hasil penelitian di atas, pengembangan dan bimbingan literasi lingkungan juga penting untuk program pendidikan lingkungan [16-17]. Bukan berarti pendekatan yang ditawarkan oleh beberapa peneliti sebelumnya tidak efektif. Namun, menurut hemat penulis, faktor utamanya adalah pada kurangnya literasi lingkungan yang dimiliki generasi saat ini. Analisa penulis didasarkan pada beberapa kasus, misalnya penelitian Anwar, Sjoraida dan Rahman terkait sosialisasi pembuatan sungai menjadi harum di Bandung, Jawa Barat, Indonesia. Dengan sosialisasi ini, ada harapan untuk memperkenalkan literasi lingkungan kepada masyarakat, sehingga muncul ide Sungai Harum Citarum. Setelah bersosialisasi, ada serangkaian pengetahuan, keterampilan kognitif, sikap dan tanggung jawab yang diperiksa untuk memperkenalkan literasi lingkungan kepada masyarakat, terutama penduduk Citarum atas. Hasil penelitian ini menunjukkan bahwa literasi informasi lingkungan yang dimiliki oleh warga hulu Sungai Citarum tidak baik dalam memaksimalkan informasi dan pengetahuan yang mereka miliki untuk lingkungan sekitar. Meskipun, program Wangi Citarum sangat efektif dalam membawa informasi dan pengetahuan kepada masyarakat dalam mengatasi sampah yang dibuang ke sungai [18]. Wu, Cheng dan Zhang melalui riset pendidikan lingkungan dan penilaian literasi lingkungan warga tentang konstruksi kota berkelanjutan di Beijing mengatakan bahwa literasi lingkungan warga adalah faktor yang menentukan. Mereka mengatakan media massa merupakan saluran penting untuk pendidikan lingkungan dan preferensi penggunaan serta frekuensi media baru seperti MicroBlog, WeChat, dan aplikasi video pendek jauh lebih tinggi daripada media tradisional seperti televisi dan surat kabar. Literasi lingkungan adalah salah satu fokus penelitian ini yang akan dielaborasi kemudian [19].

Tujuan pendidikan lingkungan dapat didefinisikan sebagai kepekaan dan kesadaran terhadap lingkungan secara komprehensif dan mencoba untuk menyelesaikan masalah atau pemahaman dasar tentang lingkungan; perasaan prihatin meningkatkan dan melindungi lingkungan; keterampilan untuk mengidentifikasi atau memecahkan masalah lingkungan; dan selalu berpartisipasi di semua tingkatan dalam bekerja menuju penyelesaian masalah lingkungan [20-22]. Dalam konteks ini, perilaku dan etika masyarakat sangat menentukan. Perilaku manusia berdasarkan kepedulian lingkungan dan etika lingkungan dapat meningkatkan kualitas pemeliharaan lingkungan [23]. Perilaku ramah lingkungan dirangsang oleh pemahaman kognitif tentang konsep lingkungan penting yang terkait dengan pengelolaan lingkungan [24]. Memahami konsep itu menjadi sangat penting sebagai landasan 
menyangkut kesiapan berperilaku yang disebut literasi lingkungan [25]. Manifestasi masyarakat yang memiliki literasi lingkungan ditunjukkan oleh bentuk masyarakat yang bersifat peduli lingkungan [26].

Para ahli pendidikan lingkungan mengemukakan bahwa beberapa orang belum atau tidak menggunakan kesadaran lingkungan mereka, baik sikap maupun perilaku yang bertanggung jawab terhadap lingkungan [27-29]. Karena itu, para ahli percaya bahwa ada celah antara pola kognitif dan perilaku manusia [30]. Ini menunjukkan bahwa proses pendidikan tidak terintegrasi, sebagian masih terpisah antara aspek kognitif, afektif dan psikomotorik. Dalam konteks Islam, pendidikan terkait dengan aspek afektif masih terbatas pada pendidikan agama dan karakter, yang terpisah dari bidang ilmu lain di Indonesia. Ini membawa implikasi pada paradigma dikotomi ilmu pengetahuan. [31]. Sehingga itu, penting untuk mengintegrasikan ilmu pengetahuan dengan nilai-nilai Islam. Ada hubungan antara keyakinan agama dengan penelitian dan penemuan sains oleh para ilmuan. Hasil menunjukkan bahwa nilai-nilai agama memengaruhi penemuan ilmiah yang dilakukan oleh para ilmuan [32]. Sementara Pendidikan karakter melalui pendidikan lingkungan masih menghadapi berbagai kelemahan, di mana proses pembelajaran didominasi oleh isi pengetahuan yang tidak berlaku untuk siswa, sehingga tidak dapat membangun dan memahami secara mendalam arti dari sifat peduli dan melestarikan lingkungan [33]. Pendidikan lingkungan belum dikaitkan dengan masalah nyata dan berisi hal-hal praktis dari kehidupan nyata di sekitar siswa. Dalam kontes ini, pembelajaran harus diarahkan dan memberikan siswa segudang pengalaman untuk memecahkan masalah lingkungan yang sekarang menjadi masalah global. Gagasan konstruktif, membangun literasi lingkungan, berperilaku dengan cara yang lebih bertanggung jawab terhadap lingkungan adalah tujuan dari pendidikan lingkungan [34-35].

Selain itu, masalah lingkungan tidak pernah lepas dari masalah sosial, baik yang berdampak langsung maupun tidak langsung pada kelangsungan hidup manusia. Oleh karena itu, penting juga pembelajaran berbasis masalah sosial. Pembelajaran berbasis socio-scientific issues (SSI) adalah pembelajaran yang bertujuan untuk melibatkan siswa dalam pengambilan keputusan masalah sosial saat ini dengan implikasi moral yang melekat dalam konteks ilmiah [36]. Selain itu, pembelajaran berbasis socio-scientific issues dapat digunakan untuk membuat pembelajaran sains lebih relevan dengan konteks kehidupan sehari-hari siswa, mengarahkan hasil pembelajaran, meningkatkan kemampuan untuk mengevaluasi informasi ilmiah, meningkatkan dialog argumentasi, dan mengembangkan literasi sains [37]. Artikel ini kemudian akan mengelaborasi lebih dalam mengenai lingkungan belajar melalui problem-based learning (PBL) dan mengaitkan dengan nilai-nilai Islam terintegrasi socio-scientific issues untuk meningkatkan literasi lingkungan dan sikap peduli lingkungan.

\section{Hasil dan Pembahasan}

Integrasi merupakan upaya untuk mempertemukan ilmu sains atau ilmu sosial ke dalam ilmu agama [38]. Pendekatan ini muncul karena adanya dikotomi ilmu dari berbagai disiplin ilmu. Integrasi adalah pendekatan yang berusaha saling menghargai antara keilmuan umum dan agama, sadar akan keterbatasan masing-masing dalam memecahkan permasalahan manusia, dan akan melahirkan sebuah kerjasama, setidaknya saling memahami pendekatan dan metode berpikir antara kedua keilmuan. Scheitle dan Ecklund melalui penelitian mereka menguji bagaimana dua orang yang mempopulerkan sains seperti Francis Collins dan Richard Dawkins memengaruhi persepsi tentang batas-batas antara agama dan sains. Penelitian mereka selanjutnya menemukan bahwa pembelajaran Dawkins tidak memengaruhi persepsi orang tentang hubungan agama-sains, sementara pembelajaran Collins menggeser responden ke arah pandangan kolaboratif antara agama dan sains [39].

Integrasi atau Islamisasi ilmu pengetahuan dilakukan kalangan intelektual Muslim, tidak lepas dari kesadaran beragama [40] di tengah ramainya arus globalisasi yang sarat dengan kemajuan ilmu 
pengetahuan dan teknologi. Sebuah gagasan lahir dengan optimis bahwa umat Muslim akan maju menyamai orang Barat apabila mampu menstransformasikan dan menyerap secara aktual ilmu pengetahuan dalam rangka memahami wahyu, atau mampu memahami wahyu dalam mengembangkan ilmu pengetahuan. Sudah tertanam di fikiran sebagian besar umat Muslim bahwa sains sebagai citra modernitas Barat sebagaiman yang dikemukan Jones, Catto, Kaden, \& ElsdonBaker [41]. Di samping itu, terdapat asumsi bahwa ilmu pengetahuan yang berasal dari Barat dianggap sebagai pengetahuan yang sekuler oleh karenanya ilmu tersebut harus ditolak, atau minimal ilmu pengetahuan tersebut harus dimaknai dan diterjemahkan dengan pemahaman secara Islami [42].

Ilmu pengetahuan untuk mempelajari sifat materi berdasarkan hukum alam berlaku secara obyektif, ilmiah dan tidak berubah. Kekuatan hukum kodrat diungkapkan dalam Q.S. [25]:2. Sementara integrasi nilai-nilai Islam dapat dipahami dari berbagai firman Allah, misalnya dalam Q.S. [3]:190-191. Ayat tersebut menunjukkan bahwa penciptaan langit dan bumi dan pergantian siang dan malam erat kaitannya dengan pikiran dan iman manusia. Misalnya, dimensi indera diwakili oleh kata "berpikir" yang tentu harus disertai dengan pengamatan dan analisis, serta kesadaran akan keteraturan segala sesuatu yang ada. Internalisasi nilai-nilai Islam dalam proses pembelajaran pada prinsipnya menjadikan segala sesuatu pemberian Allah sebagai referensi dalam memahami materi dan proses memperoleh pengetahuan. Oleh karena itu, proses belajar kaitannya dengan sains dikatakan mengandung nilai-nilai Islam jika fase pembelajaran dimulai dari langkah memahami urutan penciptaan-Nya, memahami keindahan dan mengaitkan keteraturan dan keindahan dengan kesadaran.

Islam adalah agama yang tidak hanya mengatur hubungan manusia dengan Tuhan, akan tetapi juga hubungan manusia dengan sesama makhluk. Hal-hal tersebut memiliki landasan normatif, baik secara implisit maupun eksplisit tentang menjaga dan melestarikan lingkungan hidup. Misal, tentang tugas melestarikan lingkungan hidup yang merupakan manifestasi iman (Q.S. [7]: 85), merusak lingkungan merupakan sifat orang munafik (Q.S. [2]: 205), alam semesta merupakan anugerah dari Tuhan untuk manusia (Q.S. [31]: 20) dan (Q.S. [14]: 32-33), manusia adalah wakil Tuhan untuk menjaga kemakmuran lingkungan hidup (Q.S. [6]: 165), dan kerusakan yang terjadi di muka bumi akibat dari ulah tangan manusia yang tidak bertanggung jawab (Q.S. [42]: 30) dan Q.S. [7]: 56). Alam semesta dan isinya dibuat Allah untuk manusia, sehingga manusia menempati posisi paling penting di lingkungan untuk melindungi lingkungan dari kerusakan dan memastikan keberlanjutannya. Misi Islam pada dasarnya termasuk mempertahankan dan memelihara alam semesta. Merawat alam adalah bagian integral dari implementasi ajaran Islam secara keseluruhan. Tugas manusia sebagai khalifah menuntut interaksi antara sesama manusia dan manusia dengan alam. Interaksi itu harmonis sesuai dengan instruksi yang terkandung dalam al-Quran. Prinsip dasar interaksi antara sesama manusia dan lingkungan merupakan tujuan dari semua etika agama.

Manusia berkewajiban merawat lingkungan demi kelangsungan hidup, tidak hanya untuk manusia tetapi untuk semua makhluk hidup. Tindakan manusia dalam penggunaan sumber daya alam yang berlebihan, mengabaikan pemeliharaan, konservasi dasar yang mengakibatkan degradasi dan kerusakan lingkungan, semuanya dilarang dalam Islam. Nabi SAW meletakkan prinsip umum pelestarian lingkungan dalam bentuk larangan perusakan alam, seperti melarang polusi lingkungan, membuang sampah di sumber air, di pinggir jalan, dan di bawah naungan pohon. Terdapat banyak nilai pendidikan yang bisa diambil ketika manusia berinteraksi dengan lingkungan, yakni menghormati alam; tanggung jawab moral untuk alam; prinsip cinta dan kepedulian terhadap lingkungan (peduli alam); prinsip umat manusia. Selain perintah membaca (iqra), ada beberapa metode pengajaran yang dapat digunakan dalam mengajarkan nilai-nilai Islam, yakni metode analogi (amtsal), dorongan dan peringatan (targhib dan tarhib), serta metode dialog (hiwar).

Kaitannya dengan konteks penelitian, pembelajaran berbasis masalah adalah pendekatan pembelajaran menggunakan masalah sebagai titik awal untuk belajar. Pelajaran ini mengarahkan siswa untuk mencari dan menentukan sumber yang relevan dengan pengetahuan. Dengan demikian, 
pembelajaran ini menantang siswa untuk membangun pengetahuan secara mandiri, dengan bimbingan guru. Peran guru sebagai fasilitator membantu siswa sejak awal, menemani siswa ketika siswa mengalami kesulitan. Ini sesuai dengan pandangan konstruktivisme yang didukung oleh teori pembelajaran Ausubel di mana guru harus dapat mengembangkan potensi kognitif siswa melalui proses belajar bermakna. Mereka yang berada pada tingkat pendidikan dasar misalnya, akan lebih bermanfaat jika siswa diajak beraktivitas dan dilibatkan langsung dalam kegiatan pembelajaran. Selain itu, proses pembelajaran berbasis masalah mendukung pembelajaran aktif, kolaboratif yang berpusat pada siswa, dan mengembangkan keterampilan pemecahan masalah serta belajar mandiri untuk mengasa kemampuan sebagai sarana menghadapi tantangan kompleks ke depan. Pembelajaran ini dapat mengembangkan dasar-dasar pengetahuan yang substansial dengan pemecahan masalah secara terstruktur. Melalui situasi ini, siswa mendapat kesempatan belajar. Pembelajaran berbasis masalah akan lebih bermakna jika pengajaran menggunakan konteks. Konteks yang dapat digunakan adalah pembelajaran berbasis socio-scientific issues sebagai pendekatan pembelajaran yang memerhatikan fakta dan fenomena berdasarkan masalah sosial terkait dengan sains yang ada di masyarakat. Masalah ini bersifat kontroversial tetapi memiliki elemen tambahan yang memerlukan tingkat penalaran moral atau etika dalam pengambilan keputusan dalam menyelesaikan masalah yang dihadapi.

Masalah kontekstual yang dibahas sangat memotivasi siswa dan ini menekankan pentingnya pembelajaran sains di sekolah yang berhubungan dengan masalah sosial-sains. Hubungan kontekstual, epistemologis, emosional, dan sosial-budaya memengaruhi proses argumentasi siswa pada masalah kontroversial. Pembelajaran berbasis socio-scientific issues dapat meningkatkan pemahaman konsep sains dan hubungan antara sains dengan lingkungan. Di sini terlihat bahwa orang-orang yang memiliki literasi lingkungan adalah mereka yang memiliki keterampilan dasar, pemahaman dan perasaan terkait hubungan manusia dengan lingkungan. Seseorang dengan literasi lingkungan harus memahami keterkaitan sistem alam dan sosial, kesatuan manusia dengan alam, bagaimana teknologi memengaruhi keputusan isu lingkungan dan pembelajaran tentang lingkungan sebagai upaya seumur hidup. Komponen utama dari melek lingkungan adalah pengetahuan, sikap, motivasi, kemampuan kognitif, keterampilan, dan kemauan untuk bertindak atas dasar lingkungan. Sementara status literasi lingkungan seseorang dapat diukur berdasarkan kriteria komponen literasi, yakni pengetahuan, kemampuan kognitif, keterampilan, sikap dan perilaku yang bertanggung jawab terhadap lingkungan. Kepedulian lingkungan adalah konstruksi penting dalam psikologi lingkungan. Kepedulian lingkungan sebagai kecenderungan psikologis diekspresikan dengan mengevaluasi lingkungan melalui berbagai tingkatan, yakni kepedulian lingkungan; kenikmatan alam; dukungan untuk konservasi intervensionis kebijakan; aktivisme gerakan lingkungan; konservasi dimotivasi oleh kepedulian antroposentris; keyakinan terhadap sains dan teknologi; ancaman lingkungan; mengubah alam; perilaku konservasi pribadi; dominasi manusia atas alam; pemanfaatan alam oleh manusia; kekhawatiran ekosentris; dan dukungan untuk kebijakan pertumbuhan penduduk.

Dalam konteks penelitian ini, pembelajaran berbasis masalah (problem-based learning) dikontekstualisasikan dengan masalah sosio-ilmiah (socio-scientific issues) berpotensi memperkuat kesiapan berperilaku ramah lingkungan karena menuntut siswa aktif dalam mengembangkan kreativitas mereka, merangsang proses berpikir dengan memicu aktivasi semua indera, terlibat penuh dalam proses pembelajaran sehingga dapat memperoleh pengetahuan yang lebih dalam, dan meningkatkan kemampuan siswa dalam menguasai materi pembelajaran. Hal-hal yang harus diperhatikan dalam pengajaran socio-scientific issues, yakni (1) instruksi harus dimulai dengan socioscientific issues dan pengalaman pembelajaran selanjutnya harus terus terhubung kembali ke fokus masalah; (2) siswa harus memiliki kesempatan untuk terlibat dengan praktik ilmiah, konten dan bukti saat mereka memahami masalah yang ada; (3) siswa harus menggunakan media untuk mengakses informasi tentang masalah; (4) siswa harus memiliki kesempatan untuk mengeksplorasi dimensi 
socio-scientific issues; dan, (5) pengalaman pembelajaran berbasis isu harus diakhiri dengan latihan yang memuncak sehingga peserta didik dapat mensintesiskan posisi pribadi mereka pada masalah tersebut. Dengan demikian, pengetahuan yang diperoleh dalam proses pendidikan dapat memengaruhi persepsi siswa. Persepsi pada akhirnya akan memengaruhi bagaimana siswa dalam bersikap dan bertindak. Kepedulian lingkungan dimulai dari persepsi peduli lingkungan. Jika persepsi siswa positif, maka sikap dan tindakan yang ditunjukkan juga positif.

\section{Kesimpulan}

Penelitian ini menyimpulkan bahwa Upaya pemecahan masalah dengan konteks socio-scientific issues memperkuat keterlibatan siswa dalam masalah lingkungan, dan keterlibatan siswa pada akhirnya dapat meningkatkan pemahaman tentang masalah lingkungan, utamanya dalam pemecahan masalah dan pencarian solusi. Pengetahuan yang terintegrasi dengan nilai-nilai Islam diyakini memengaruhi pola pikir dan persepsi siswa. Etika dan kepekaan terhadap lingkungan dimulai dengan cara pandang dan tindakannya terhadap lingkungan. Konsep pendidikan lingkungan yang efektif dapat memperkuat literasi lingkungan dan kesiapan untuk berperilaku ramah lingkungan.

\section{Referensi}

[1] J. Xu 2020 Research on the role of new electronic information technology in the development of modern avionics equipment $M S \& E .7501012021$

[2] I. Lyskova, \& O. Rudakova 2020 Agile management as a technology of professional development of the human resources in a credit organization In 5th International Conference on Economics, Management, Law and Education (EMLE 2019). Atlantis Press. 405-409

[3] L. Valera, \& J. C. Castilla 2020 New questions on global environmental changes and ethics in the contemporary technological world In Global Changes. Springer, Cham. 191-194

[4] O. V. Levaschova, \& N. V. Morgacheva 2020 Environmental supervision (control) in the area of new technology appliance In IOP Conference Series: Earth and Environmental Science. IOP Publishing. 4216062004

[5] J. Zhang 2020 Environmental problems of human settlements and countermeasures based on ecological engineering In Study of Ecological Engineering of Human Settlements. Springer, Singapore. 1-39

[6] C. Zafer, \& P. Vardarlier 2020 The impact of new technology on society and workforce in production in the era of industry 4.0 In Handbook of Research on Strategic Fit and Design in Business Ecosystems. IGI Global. 395-411

[7] S. Singh, P. Dixit, K. S. Rathore, \& N. Sharma 2020 Detrimental impact of plastic outcome on agriculture: Biggest threat to environment In Handbook of Research on Environmental and Human Health Impacts of Plastic Pollution. IGI Global. 122-141

[8] M. DiGiuseppe, P. Elliott, S. I. Khan, S. Rhodes, J. Scott, \& A. Steele 2019 Rising to the challenge: Promoting environmental education in three Ontario faculties of education In Environmental and Sustainability Education in Teacher Education. Springer, Cham. 131159

[9] S. Ramadhan, E. Sukma, \& V. Indriyani 2019 Environmental education and disaster mitigation through language learning In IOP Conference Series: Earth and Environmental Science. IOP Publishing. 3141012054

[10] S. Kuraedah, F. Gunawan, I. S. Wekke, \& B. Hamuddin 2018 Learning environment construction in Islamic Higher Education: Connecting the puzzles of ideas In IOP Conference Series: Earth and Environmental Science. IOP Publishing. 1751012107 
[11] J. La Fua, R. U. Nurlila, F. Gunawan, \& I. S. Wekke 2018 Islamic education on formation of environmental awareness in Indonesian Islamic Boarding Schools In IOP Conference Series: Earth and Environmental Science. IOP Publishing.156 1012035

[12] Z. L. Bedural 2018. Association between educational attainment and Filipinos'values, attitudes and actions towards the environment Journal of Sustainable Development Education and Research. 21 59-67

[13] A. Suryani, S. Soedarso, M. Saifulloh, Z. Muhibbin, W. Wahyuddin, T. Hanoraga, \& D. Rahmawati 2019 Education for environmental sustainability: a green school development IPTEK Journal of Proceedings Series. 6 65-72

[14] M. K. Yasin 2019 Character education for environmental awareness through the adiwiyata program Islamic Studies Journal for Social Transformation. 127-145

[15] E. Saprodi, W. Kastolani, \& E. Ningrum 2019 Integration of environmental education in eco pesantren Daarut Tauhiid Bandung Proceeding International Conference on Science, Technology, and Humanity (ISETH 2019).

[16] I. Wilujeng, W. S. B. Dwandaru, \& R. B. A. Rauf 2019 The effectiveness of education for environmental sustainable development to enhance environmental literacy in science education: A case study of hydropower Jurnal Pendidikan IPA Indonesia, 8(4), 521-528.

[17] H. Veisi, M. Lacy, S. Mafakheri, \& F. Razaghi 2019 Assessing environmental literacy of university students: A case study of Shahid Beheshti University in Iran Applied Environmental Education \& Communication. $18125-42$

[18] R. K. Anwar, D. F. Sjoraida, \& M. T. Rahman 2019 Socializing fragrant river program as a strategy for introducing environmental literacy to the upper Citarum community Journal of Environmental Management and Tourism. 103 597-612

[19] E. Wu, J. Q. Cheng, \& J. B. Zhang 2020 Study on the environmental education demand and environmental literacy assessment of citizens in sustainable urban construction in Beijing Sustainability. 121241

[20] A. A. D. A. Khalid 2020 How to promote education for sustainable development? Vision of the educational situation and its contribution to sustainable development The Eurasia Proceedings of Educational and Social Sciences. 15 6-12

[21] S. Shava, M. V. Makokotlela, \& H. Hebe 2020 Role of SDGs in reconceptualising the education for sustainable development curriculum in higher education in South Africa In Scaling up SDGs Implementation. Springer, Cham. 169-179

[22] S. Benzer, R. Benzer, \& Ş. Bozkurt 2020 Investigation of the attitudes for environment and evaluation of artificial neural networks In Advanced MIS and Digital Transformation for Increased Creativity and Innovation in Business. IGI Global. 1-25

[23] M. A. Muflihaini, \& Ertando 2020 How is the attitude of students' environmental literacy through the myth of beringin (Ficus sp.) in adiwiyata school? In Journal of Physics: Conference Series. IOP Publishing. 14401012066

[24] P. Kautish, \& R. Sharma 2020 Determinants of pro-environmental behavior and environmentally conscious consumer behavior: An empirical investigation from emerging market Business Strategy \& Development. 31 112-127

[25] P. Brereton 2020 Environmental literacy: An overview-case study readings of oblivion (2013) and hacksaw ridge (2016) In Handbook of Research on Multidisciplinary Approaches to Literacy in the Digital Age. IGI Global. 36-54

[26] Z. Long, S. Wang, X. Gu, Y. Sun, J. Yu, \& J. Yang 2020 comparative analysis of adult and adolescent environmental awareness and intervention of adolescent environmental awareness E\&ES. 4463032070 
[27] L. Fu, Z. Sun, L. Zha, F. Liu, L. He, X. Sun, \& X. Jing 2020 Environmental awareness and proenvironmental behavior within China's road freight transportation industry: Moderating role of perceived policy effectiveness Journal of Cleaner Production. 252119796

[28] D. Thor, \& P. Karlsudd 2020 Teaching and fostering an active environmental awareness design, validation and planning for action-oriented environmental education Sustainability. 128 3209

[29] E. M. Nkoana 2020 Exploring the effects of an environmental education course on the awareness and perceptions of climate change risks among seventh and eighth grade learners in South Africa International Research in Geographical and Environmental Education. 291 7-22

[30] X. Wang, X. Qin, \& Y. Zhou 2020 A comparative study of relative roles and sequences of cognitive and affective attitudes on tourists' pro-environmental behavioral intention Journal of Sustainable Tourism. 285 727-746

[31] M. Nasir 2020 Reconstructing distinction pattern of science education curriculum in Indonesian Islamic Universities: An integrated paradigm for science and religion Journal of Turkish Science Education. 17 11-21

[32] O. Tomyuk, A. Shutaleva, M. Dyachkova, \& A. Y. Dudchik 2020 Values and science In International Session of Factors of Regional Extensive Development (FRED-2019). Atlantis Press.

[33] N. Rahman, \& A. A. Purwoko 2020 Development of subjects specific pedagogy to build environmental awareness character on students in mining areas In IOP Conference Series: Earth and Environmental Science. IOP Publishing. 4131012033

[34] C. S. Ahn 2020 Considering the role of documentary media in environmental education Journal of the Canadian Association for Curriculum Studies. 172 67-79

[35] A. Andriansyah, T. Taufiqurokhman, \& I. S. Wekke 2019 Impact of environmental policy factors on tourism industry: A study from Indonesia over last three decades International Journal of Energy Economics and Policy. 93360

[36] R. Amos, M. C. Knippels, \& R. Levinson 2020 Socio-scientific inquiry-based learning: possibilities and challenges for teacher education In Science Teacher Education for Responsible Citizenshi. Springer, Cham. 41-61

[37] J. A. Foulk, P. J. Friedrichsen, \& T. D. Sadler 2020 Science in socio-scientific issues: Teaching with a timeline activity The Science Teacher. 87735

[38] S. Erduran 2020 Argumentation in science and religion: match and/or mismatch when applied in teaching and learning? Journal of Education for Teaching. 1-3

[39] C. P. Scheitle, \& E. H. Ecklund 2017 The influence of science popularizers on the public's view of religion and science: An experimental assessment Public Understanding of Science. 26 $125-39$

[40] M. R. Ibrahim 2015 The integration of Islam and science: Al-Ghazali on causality revisited 'Ulüm Islāmiyyah Journal. 1973584 1-9

[41] S. H. Jones, R. Catto, T. Kaden, \& F. Elsdon-Baker 2019 That's how Muslims are required to view the world': Race, culture and belief in non-Muslims' descriptions of Islam and science The Sociological Review. 67 1 161-177

[42] A. Y. Nuryantini, K. Karman, \& A. Holik 2018 Integration science and religion: An analysis in Islamic higher education Tarbiya: Journal of Education in Muslim Society. 51 11-18 